\title{
PEMANFAATAN LIMBAH KOKON ULAT SUTRA (Bombyx mori.L) SEBAGAI SERUM ANTI-AGING
}

\author{
oleh \\ Rosa Paembonan $^{* 1}$, Nurul Salama ${ }^{1}$, Desi Ramadani ${ }^{1}$, Al Gazali ${ }^{2}$ \\ E-mail: paembonanrosa@gmail.com \\ ${ }^{1}$ Fakultas Teknik, Universitas Bosowa \\ ${ }^{2}$ Fakultas Teknik, Universitas Bosowa,
}

\begin{abstract}
ABSTACK
Cocoon is a product produced by silkworms (Bombyx mori), many contain ceresin that wraps filaments on fibroin fibers in the coke, weighing 20-30\% of the total weight of the cocoon. This ceresin is one of the antioxidants that helps reduce the aging process caused by free radicals. Ceresin obtained from both frozen cocoon and defective cocoon, is expected to be formulated into serum waste coke as anti-aging (anti-aging). Serum is one of the cosmetic content in the form of gel or liquid used for anti-aging products, then carried out research utilization of waste cocoon silkworm (bombyx mori) as an anti-aging serum. The expected result is obtained serum available that has the potential to be an anti-aging serum. The method used in the implementation of this study is the literature review obtained that silkworm cocoon has a high content of ceresin compounds that have not been processed into a product, this ceresin compound is usually made as an antioxidant, bleach, sunscreen, anti-agent, antibacterial and healing compound. The lack of utilization of silkworm cocoon waste is a problem that must be reviewed and needs to be found a solution by utilizing silkworm cocoon waste into an anti-aging serum.
\end{abstract}

Keywords: silkworm cocoon, serum, anti-aging, ceresin, antioxidant.

\begin{abstract}
ABSTRAK
Kokon merupakan produk yang dihasilkan oleh ulat sutera (Bombyx mori), banyak mengandung serisin yang membungkus filamen pada serat fibroin pada kokon, bobotnya $20-30 \%$ dari bobot total kokon. Serisin ini merupakan salah satu antioksidan yang bermanfaat mengurangi proses aging yang disebabkan radikal bebas. Serisin didapatkan dari kokon bekualitas baik maupun kokon cacat, diharapkan dapat diformulasi menjadi sediaan serum limbah kokon sebagi anti-aging (anti penuaan kulit). Serum adalah salah satu sediaan kosmetik berbentuk gel atau cair yang digunakan untuk produk anti-aging, maka dilakukan penelitian pemanfaatan limbah kokon ulat sutera (bombyx mori) sebagai serum anti-aging.. Hasil yang diharapkan yaitu diperoleh sediaan serum yang berpotensi menjadi serum anti-aging. Metode yang digunakan dalam pelaksanaan penelitian ini adalah literatur review didapatkan bahwa Kokon ulat sutera memiliki kandungan senyawa serisin yang cukup tinggi yang belum diolah menjadi sebuah produk, Senyawa serisin ini biasanya dibuat sebagai sediaan antioksidan, pemutih, tabir surya, antiagent, antibakteri dan penyembuh. Kurangnya pemanfaatan limbah kokon ulat sutra merupakan masalah yang harus dikaji dan perlu dicarikan solusi dengan memanfaatkan limbah kokon ulat sutra menjadi serum antiaging.
\end{abstract}

Kata Kunci: Limbah kokon, serum, anti-aging, serisin, antioksidan 


\section{A. PENDAHULUAN}

Penuaan pada kulit merupakan proses biologis kompleks yang tentu tidak bisa terhindarkan. Tanda-tanda ekternal penuaan kulit yaitu kerutan halus, kulit tipis dan transparan, bintik-bintik pigmen, kulit kendur, kulit kering, rambut beruban, rambut rontok, kulit tidak mampu berketingat, penipisan lempeng kuku dll (Mackiewicz and Rimkevicius, 2008). Penyebab penuaan kulit yang sulit terhindarkan adalah radikal bebas ROS (Reaktive Oxygen Species) dimana, radikal bebas salah satunya bersumber dari radikal UV (Masaki, 2010). Senyawa yang dapat menangkal radikal bebas adalah antioksidan. Salah satu penghasil antioksidan yang belum diolah menjadi produk adalah kokon dari Ulat sutera.

Kokon merupakan produk yang dihasilkan oleh ulat sutera domestikasi seperti Bombyx mori maupun ulat sutera liar seperti Attacus atlas. Kulit kokon merupakan bahan pokok pembuatan benang sutera yang selanjutnya dapat diolah menjadi kain maupun pakaian. Serisin adalah salah satu protein pada kokon yang mengandung 18 jenis asam amino dan berkontribusi sebesar 20\%$30 \%$ terhadap berat kulit kokon utuh (Zaradina, 2016).
Kokon ulat sutera memiliki kandungan senyawa serisin yang cukup tinggiyang berpotensi sebagai antioksidan (Devi, 2011) , senyawa serisin ini biasanya dibuat sebagai sediaan antioksidan, pemutih, tabir surya, antiagent, antibakteri dan penyembuh luka (Kementerian Perindustrian RI, 2018). Serisin tidak hanya didapatkan dari kokon bekualitas baik saja namun juga dari kokon cacat. Jumah kokon cacat yang dihasilkan bisa mencapai $8,78 \%$ dari total produksi kokon (Media Indonesia, 2018).

Kokon yang dianggap cacat sudah dianggap limbah bagi petani. Menurut pengelola usaha benang sutera, pemanfaatan limbah kokon ini digunakan oleh masyarakat diolah menjadi bentuk kerajinan tangan, belum diolah menjadi produk. Beberapa bentuk limbah kokon antara lainnya kokon ganda (kokon yang dibuat oleh dua ekor ulat bersamasama,menghasilkan kokon yang besar sehingga lapisan sutera tebal dan berkerut kasar), kokon bernoda dalam (kokon yang pupanya mati atau teluka didalam sehingga kokonnya ternoda didalam), kokon bernoda luar (kokon yang ternoda oleh kotoran atau ulat mati dibagian luarnya), kokon berujung tipis (Kulit kokon yang tipis pada bagian ujungnya) (Media Indonesia, 2018). 
Penghasil kokon terbesar di Indonesia salah satunya adalah pengusahaan sutera alam di Kabupaten Soppeng pada tahun 2010 memiliki luas lahan murbei 79,92 ha, produksi kokon $13.669,08 \mathrm{~kg}$ kokon dan produktivitas kokon 171,03 $\mathrm{kg} / \mathrm{ha}$ tanaman murbei (Sadapotto, 2011). Tingginya produksi kokon tentu sangat meningkatkan perekonomian warga kabupaten Soppeng. Oleh karena itu akan dilakukan penelitian untuk membuat sediaan serum dari limbah kokon ulat sutera agar dapat meningkatkan nilai guna dari limbah kokon ulat sutera ini.

Limbah kokon yang akan digunakan diperoleh dari daerah Kec Donri-Donri Kab. Soppeng yang merupakan limbah kokon tidak digunakan sehingga hanya terbuang secara pecuma. Limbah inilah yang akan dibuat produk farmasi serum anti-aging, dimana serum merupakan produk konsentrat tinggi yang mengandung zat aktif dalam jumlah yang relatif banyak dan penggunaannya sangat mudah dengan hanya mengoleskan pada wajah yang bersih.

\section{B. METODE PRNELITIAN}

Metode yang digunakan dalam pelaksanaan penelitian ini adalah deskripisi kualitatif melalui literatur review yaitu literatur dari berbagai sumber di review dan dilakukan analisis komparatif, deskripsi dan analisis data dengan teknik pengumpulan dengan trianggulasi (gabungan), analisis data bersifat induktif. Jurnal yang digunakan dalam literatur review yakni jurnal Nasional, Jurnal Internasional serta artikel ilmiah yang terkait dengan judul.

\section{HASIL DAN PEMBAHASAN}

Kokon limbah ulat sutera (bombyx mori) salah satu potensi sumber daya alam di Indonesia. Kokon tersebut memiliki kandungan antioksidan yang menjadi kokon ini dimanfaatkan menjadi gel anti jerawat dan pelembab kulit. Hasil penelitian Jin (2007) dan Devi (2011) bahwa pemeliharaan ulat sutra merupakan masa yang sangat menguntungkan tidak saja untuk mendapatkan kokon yang merupakan bahan baku benang sutera, yang diperlukan di dunia (fashion), tetapi juga untuk mendapatkan bahan antioksidan. Sependapat Zaradina (2016) kokon merupakan produk yang dihasilkan oleh ulat sutera domestikasi seperti Bombyx mori maupun ulat sutera liar seperti Attacus atlas. Kulit kokon merupakan bahan pokok pembuatan benang sutera yang selanjutnya dapat diolah menjadi kain maupun pakaian.

Tidak semua ulat sutera dapat menghasilkan kokon yang berkualitas 
baik, dalam arti bahwa filamen yang diuraikan dari kokon yang berkualitas baik tidak terputus dari awal sampai akhir , sampai seluruh serat dalam kokon habis. Kokon yang tidak dapat diuraikan menjadi filamen dianggap sebagai limbah kokon, yang pada umumnya berasal dari :

a. Kokon yang berlubang karena kepompong sampai menjadi kupukupu dan keluar dari kokon.

b. Kokon yang cacat, misalnya kokon yang rangkap atau tidak normal atau sangat kecil.

c. Sisa kokon yang direeling (diuraikan) yang masih terdapat sisa serat sutera tetapi sukar untuk ditarik dan diuraikan (Asep Subagia, 1998)

Serat sutera alami menurut Fabiani (1996) terdiri dari dua jenis protein yaitu fibrion dan serisin. Protein fibrion merupakan protein serat sedangkan serisin merupakan perekatnya. Masahiro (1982) dan hasilnya serisin membungkus filamen yang sangat kecil yaitu serat fibrion pada kokon, bobotnya 20-30\% dari bobot total kokon. Serisin merupakan jenis protein globular yang larut dalam air. Dinyatakan oleh Lehninger (1982) protein tersusun dari asam amino dengan urutan yang khas. Ditambahkan Wei (2005) Protein serisin bombyx mori terdiri dari 18 jenis asam amino yang sebagian besar merupakan kelompok senyawa polar kuat, seperti senyawa yang mempunyai gugus hidroksil, dan amino. Hasil penelitian Kwang (2003) melaporkan serisin dari bombx mori kaya akan serina yaitu sebesar 32\%, akan tetapi menurut laporan $\mathrm{Wu}$ (2007) menyatakan hasil serina sebesar 27,3\%, asam aspartat 18,8\%, glina $10,7 \%$ dan sedikit mengandung sistin $0,3 \%$ serta triptofa $0,4 \%$. Serisin merupakan protein dengan permukaan hidrokfilik $20 \%$ dan hidrofobik $30 \%$ (Aramwit, 2010).

Sericin telah dikembangkan secara aplikatif untuk dapat dimanfaatkan dalam berbagai kebutuhan, seperti kebutuhan didalam bidang kosmetik. Dijelaskan oleh Patel (2011) bahwa Sericin dapat meningkatkan kelembaban dan keelastisan kulit. Sependapat Kitisin, (2013) bahwa khasiat Sericin dapat dibandingkan dengan khasiat vitamin $\mathrm{C}$ dalam hal anti-aging (anti penuaan). Sericin memiliki kandungan yang mampu memberikan stimulus pada kolagen, menurunkan kematian sel pada kulit, dan mampu menekan regulasi nitrit, dimana nitrit tersebut dapat menimbulkan stresoksidatif didalam tubuh. Stresoksidatif adalah suatu keadaan dalam tubuh dimana produksi radikal bebas dan oksigenreaktif yang berlebihan sehingga 
dapat menyebabkan kerusakan sel, asia dan kaukasia. Pada wanita Asia jaringan, atau organ (Moller, 1996). manifestasi penuaan kulit yang mucul Selain itu, dalam penelitiannya yang lain, adalah bintik hitam atau lentigenes, Aramwitdkk (2010) menjelaskan bahwa sedangkan pada wanita kaukasia Sericin dapat digunakan sebagai bahan manifestasi penuaan kulit adalah kerut pembantu dalam penyembuhan luka, karena dapat meningkatkan perlekatan sel fibroblast pada manusia. Selaras pendapat Zaradina (2016) Serisin adalah salah satu protein pada kokon yang mengandung 18 jenis asam amino dan berkontribusi sebesar 20\%-30\% terhadap berat kulit kokon utuh.

Proses penuaan kulit adalah proses dinamik. Proses penuaan kulit menyebabkan perubahan histologis pada lapisan kulit (Sadick, 2009). Faktor-faktor yang mengakibatkan penuaan kulit adalah faktor intrinsik (status gizi) dan faktor ekstrinsik (sinar UV). Manifestasi penuaan kulit ditandai dengan kerut, dimana kerut terjadi akibat kehancuran DNA akibat reaksi inflamasi yang akan menghasilkan protease dan spesies oksigen reaktif yang akan menghancurkan serat elastin. Bintik hitam diakibatkan oleh jumlah melanosit per unit. Lingkaran hitam, mekanisme penipisan jaringan kulit pada pembuluh darah terlihat pada permukaan kulit sehingga tampak kehitaman (Tzanetakou et al, 2012). Pola proses penuaan kulit berbeda pada wanita (Sugita T\&Nishikawa, 2011).

Supaya radikal bebas tidak meraja lela, tubuh secara spontan akan memproduksi zat antioksidan. Definisikan antioksidan menurut Sofia (2005) sebagai inhibitor yang bekerja menghambat oksidasi dengan cara bereaksi dengan radikal bebas reaktif membentuk radikal bebas tak reaktif yang relatif stabil sehingga dapat melindungi sel dari efek berbahaya radikal bebas oksigen reaktif. Dijelaskan pula oleh Indigomarie (2009) jika di suatu tempat terjadi reaksi oksidasi dimana reaksi tersebut menghasilkan hasil samping berupa radikal bebas $(\mathrm{OH})$ maka tanpa adanya kehadiran antioksidan, radikal bebas ini akan menyerang molekul-molekul lain disekitarnya. Hasil reaksi ini akan dapat menghasilkan radikal bebas yang lain yang siap menyerang molekul yang lainnya lagi. Akhirnya akan terbentuk reaksi berantai yang sangat membahayakan. Berbeda halnya bila terdapat antioksidan. Radikal bebas akan segera bereaksi dengan sntioksidan membentuk molekul yang 
stabil dan tidak berbahaya. Reaksi pun berhenti sampai di sini.

\section{KESIMPULAN}

Kokon yang dianggap cacat sudah dianggap limbah bagi petani. Menurut pengelola usaha benang sutera, pemanfaatan limbah kokon ini digunakan oleh masyarakat diolah menjadi bentuk kerajinan tangan, belum diolah menjadi produk. Protein serisin bombyx mori terdiri dari 18 jenis asam amino yang sebagian besar merupakan kelompok senyawa polar kuat, seperti senyawa yang mempunyai gugus hidroksil, dan amino. Oleh karena itu, Limbah kokon ulat sutra dapat menjadi upaya solutif yang dapat digunakan untuk memformulai sedaan serum anti-aging .

\section{DAFTAR PUSTAKA}

Ahima RS. 2009. Connectingobesity, aging and diabetes. Nature Medicine Vol. 15, pp. 996-997

Aramwit P, Kanokpanont S, Punyarit P, Srichana T. 2010. The effect of sericin from various extraction methods on cell viability and collagen production. Int. J. Mol. Sci. 11:2200-2211.

Atmosoedarjo S, J. Kartasubrata, Kaomini M, Saleh W, Moerdako W. 2000. Sutera Alam Indonesia. Jakarta: Yayasan Sarana Wana Jaya

Devi R, Deori M, Devi D. 2011. Evaluation of antioxidant activities of silk protein Sericin secreted by silkworm Antheraea assamensis (Lepidoptera: Saturniidae). J Pharm Res. 4(12): 4688 $\square 4691$.
Calleja-Agius j and Brincat M. 2013. Skin connective tissue and aging. Best Practice and research Obs \& Gyn. Vol. 27, pp 727-740

Dianasari R. 2014. Pemberian krim ekstrak jagungungu (Zea Mays) menghambat peningkatan kadar MMP-1 dan penurunan jumlah kolagen pada tikus wistar. Universitas Udayana (Thesis).

Fabiani C, M. Pizzichini, M. Spadoni, G. Zeddita. 1996. Treatment of waste water from silk degumming processes for protein recovery and water reuse. Desalination 105:1-9.

Fisher GJ, Wang Z, Datta S et al. 1997. Pathophysiology of premature skin aging induced by ultraviolet light. NEJM. Vol 337, pp 1419-28

Guntoro, S. 1994. Budidaya Ulat Sutera. Kanisius. Yogyakarta

Jin HW, Zhang W, Shi YX. 2007. Preparation and characterization of sericin powder extracted from silk industry waste water. Food Chem. (103): 1255-1262.

Kementerian Perindustrian RI. 2018. Tingkatkan Nilai Tambah, Industri Farmasi dan Kosmetik Bisa Manfaatkan Serisin. Workshop Cloud Computing.

Kwang. 2003. Preparation of selfassembled silk sericin nanoparticles. Int J Bio Macromol 32:36-42.

Lehninger AL. 1982. Dasar-dasar biokimia jilid 2. Jakarta: Erlangga.

Mackiewicz and Rimkevicius, 2008). Skin aging. Gerontologija, 9(2): 103-108

Mahmud, H., \& Kasim, H. (2020, November). Program Kemitraan Masyarakat Pengolahan Keripik Pisang Di Kecamatan Tidore Kota Tidore Kepulauan. In Seminar Nasional Hasil Penelitian \& Pengabdian Kepada Masyarakat (SNP2M) (pp. 272-277). 
Media indonesia.2018. Industri Farmasi dan Kosmetik Diminta manfaatkan serisin. Jakarta Moller, $\mathrm{H}$ and Anders .K. 1986. Disease and parasites of marine fishes.Verlag Moller. Kiel, Germany. p: 365

Nursita ita.2017. Perbandingan produktifitas ulat Sutra dari dua tempat pembibitan yang berbeda pada kondisi lingkungan pemeliharaan panas. Universitas Brawijaya: Malang

Patel, J., G. Kevin, A. Patel, Raval, M., dan Sheth, N., 2011. Design and development of a selfnanoemulsifying drug delivery system for telmisartan for oral drug delivery. International journal of pharmaceutical investigation, $\mathbf{1}$ : 112.

Sadapotto. 2011. Perbandingan pengaruh luas lahan murbei terhadap produktivitas kokon pada tiga daerah pengembangan. Makalah disampaikan pada Seminar Nasional MAPEKI 2 Nopember 2011 di Yogyakarta

Sunanto H. 1997. Budi Daya Murbai Dan Usaha Persuteraan Alam. Yogyakarta : Kanisius

Wei T, Li MZ, Xie RJ. 2005. Preparation and structure of porous silk sericin materials. Macromolecular Materials and Engineering 290: 188-194.

Zaradina.S. 2016. Ekstraksi Serisin Kokon Bombyx Mori L. Sebagai Bahan Aktif

Krim Penyembuh Luka.[KTI]. Bogor (ID): Institut Pertanian Bogor 